\title{
The view from Marege': Australian knowledge of Makassar and the impact of the trepang industry across two centuries
}

\author{
Campbell Macknight
}

When Matthew Flinders and Robert Brown met the trepanging fleet from Makassar off north-eastern Arnhem Land in 1803 and interviewed Pobassoo, its 'old Commander', they asked a very well-informed question; according to Brown, 'They [that is, the trepangers] denied having any of their celebrated Poison wch they call Ippo, on board'. ${ }^{1}$ Given the long and complicated history of the European understanding of this poison, it is not clear how Flinders and Brown picked up the common association of 'ippo', or more usually in Malay 'upas', with Makassar. ${ }^{2}$ The significance of the question in this discussion, however, is that it demonstrates how these British observers of the trepang industry in northern Australia were able to place the trepangers within a known context. Neither Flinders nor Brown had ever visited Makassar - or would in the future, but they knew this detail about the world of South Sulawesi and the Indonesian archipelago more generally. It is a useful point from which to begin a survey of the changing attitudes of those who saw this industry in action, before turning to the outlook of those who have studied it subsequently.

Almost everyone who has written about the trepangers has been concerned to describe the nature and consequences of the interactions between these visitors and local Aboriginal people. Indeed, for most anthropologists and historians of Aboriginal societies their interest in the industry relates directly to the question of assessing the impact of this external contact on Aboriginal Australia and the response, especially in Arnhem Land. The effects of such interactions have been studied across many fields, but particularly in language, art, music, religion, health and economic life, and the memory of the industry is still strong. Yet, as we shall see, just as one cannot understand the historical sources without understanding the changing times at which they were written, so one needs to take account of the outlook and limited knowledge of later scholars in their accounts of the industry and its impact.

1 Brown journal, 18 February 1803, British Museum (Natural History). See also Flinders 1814, 2: 230; Brown 2001: 373.

2 See the seven pages of discussion and quotation in Yule and Burnell 1903: 952-959. From the form of the word used by Brown, I suspect he knew it from Rumphius. 


\section{A narrowing focus}

Three points need to be made about the general context within which Europeans made observations of trepangers and the trepanging industry up to about 1850. Firstly, there was much in common between the world of the observers and that of the trepangers. Most obviously, all the Europeans, such as Flinders, but also the British military and others at early British settlements, depended upon and were intimately familiar with the operation of sailing vessels, as were the trepangers. The praus seen by Flinders were somewhat smaller than the Investigator, but they depended on the same basic technology. Similarly, other aspects of technology, especially guns, and of social and economic organisation were not widely divergent.

Secondly, the territorial claims of the various imperial powers were far less assertive in the first half of the nineteenth century than they became towards the end of the century. Flinders and King in their meetings with the trepanging fleets were beyond even the formal boundaries of New South Wales. ${ }^{3}$ Admittedly, the western boundary of the British claim was moved in 1824 to cover the settlement of Raffles Bay, and thus all of the coast regularly visited by praus coming around the eastern end of Timor, and the remainder of the continent, including the Kimberley coast, was claimed in 1829 to cover the Swan River settlement, but there was little desire for exclusive control, even had that been possible. Conversely, in Makassar, although the praus seem to come from the area under the direct control of the Dutch East India Company in the eighteenth century - and later the Dutch colonial government, with a brief British interlude - the reality of Dutch power was rather more relaxed. Trepang was never a trade item of interest to the Dutch Company itself, though the trade in trepang, like that in all items, was recorded by the Dutch, as we shall see. Trepang was one of those items which the Company was content to leave to locally-sponsored production and independent trade with China, and the same applied to the successor governments in the nineteenth century. There was, however, much interest in the prospect of other trade between north Australia and the eastern parts of the archipelago. This motive lay behind the foundation of the Raffles Bay settlement, though nothing much came of it. One European vessel, probably the Heroine from the Port Essington settlement, is even recorded in the Makassar harbour records as bringing a few goods from 'Nieuw Holland or Marege' in 1842, and there was much coming and going from Port Essington with other closer islands. ${ }^{4}$

Thirdly, the Enlightenment view of non-Europeans persisted on the ground - or perhaps even more aptly, on the deck - long into the nineteenth century and decades after the tide of intellectual thought had moved into a concern with ranking and hierarchy. This earlier view was concerned to compare peoples and societies, rather than to place them on a ladder of development with, towards

3 Gammage 1981.

4 Spillett 1972: 85; Arsip Nasional Republik Indonesia, Jakarta, Arsip Makasar, 354.4. 
the end of the nineteenth century, clear evolutionary implications. ${ }^{5}$ If the 'other' was merely different, not lesser or lower, then there was the possibility of mutual learning. Flinders and Brown on board the trepanging prau in 1803 exemplify this attitude: they seek information of all kinds; they accept Pobassoo's warning to be careful of Aboriginal people; having discovered that the praus come from Makassar, they are happy to reply in turn that they come from Port Jackson and then to record the version of this name written in what were, to them, unfamiliar characters. ${ }^{6}$ There is a strong mutuality in this exchange. Another example of this open, comparativist view can be seen in the attitude of Collet Barker at Raffles Bay in 1828 and 1829. On 17 May 1829, just before a group of praus returned to Makassar, Barker and a group of prau captains sat down together and compared notes on maps, but this was merely the final interview in what had been nearly two months of fairly constant and friendly dealing between Barker and prau captains and their crews. ${ }^{7}$ Ten years later, George Windsor Earl, the best informed of all nineteenth-century British observers of the trepangers from his extensive experience in the archipelago, was still hearing from one of the captains Barker had met about the respect in which Barker had been held. Earl himself displays much the same open-minded curiosity about others and sympathy with the fate of individuals. ${ }^{8}$

Much of this general context changed as the nineteenth century wore on and, for our interests in the coast of northern Australia, a date of about 1850 provides a useful hinge. There were important differences between the attitudes of the earlier British hydrographers and those condemned to endure the tedium of the early settlements, on the one hand, and, on the other, the outlook of those South Australians associated with giving some reality to South Australia's possession of its Northern Territory from 1863 onwards.

There is an instructive contrast between Barker's accounts of his attempts to mediate between aggrieved trepangers and local Aborigines and Alfred Searcy's exuberant narrative of his handling of a similar situation at Melville Bay in 1884 . Barker records the arrival on 2 April 1829 of a 'very small' prau which was 'in want of everything'. It had come from just around the corner in Bowen Strait where the Aborigines had taken some rice.

One of the first things they asked was permission to proceed with a party into the country to punish [the Aborigines]. This of course I did not accede to, telling [the captain] that as we were on friendly terms with them, I could not allow any hostilities to take place from this settlement. That

5 The significance of this change in European understanding of other societies has only recently become apparent in relation to Australia, though it has a long and complex history more generally. See Macknight 2008b. In appreciating the importance of this change, I am much indebted to Carroll 2005 in particular.

6 Flinders 1814, 2: 232. Brown (2001: 373) omits the actual characters, but they are there in the original manuscript. Cense (1952: 250) seems to have been the first modern scholar to have been able to read them.

7 Mulvaney and Green 1992: 134-168.

8 Earl 1846: 56. See also Mulvaney and Green 1992: 151 for Bapa Padu. 
had he landed in the Straits I should not have interfered, but added that I should not approve of his acting even there in the manner he proposed against the blacks of our neighbourhood, who we were endeavouring to bring into some order. ${ }^{9}$

On 13 May, Barker had actually to intervene in person to prevent a party of trepangers attempting to take Aboriginal hostages to obtain the return of some stolen canoes. ${ }^{10}$

Searcy, the Sub-collector of Customs for the South Australian administration in Darwin, had hired a steamer - admittedly not a very large or comfortable one - for a voyage along the Arnhem Land coast to investigate whether some trepanging praus had by-passed the new arrangements for paying Customs duties and purchasing fishing licences. On 29 March 1884 in Melville Bay in north-eastern Arnhem Land, he found two praus; one had paid up, the other had not. '[The captain's] excuse I considered fairly good, so fined him only $£ 10$, which sum, with the dues, he paid up in gold.' Searcy also met 'a very fine, tall, well-made nigger' called Cadado.

The masters of the proas came aboard while Cadado was there, and complained that as soon as the rice was cooked for their men, the black captain and his followers took it. I talked to Cadado, and told him that if he interfered with the Malays, white men would come and growl. I also informed the Malays that in a measure they must defend themselves, but that if they used any unnecessary violence they would be punished. Cadado promised never to steal again. He must have had a relapse, however, for not long afterwards the Malays killed him. The Malays told me that they were not frightened of the natives, but were afraid that the whites would punish them if they interfered with the blacks. I did not believe this at the time, but it seemed as if it were a fact. ${ }^{11}$

The essential point of the British intervention in both cases is the same: both Barker and Searcy urge the trepangers not to resort to violence. But notice the differences. Searcy has a steamer, not a sailing vessel, and, as he makes clear elsewhere, 'I always used a Martini-Henry carbine when after big game.' ${ }^{12}$ There was no shortage of the latest ordnance aboard his steamer. Moreover he has no hesitation in applying the requirement to pay the imposts of the colonial administration of the Northern Territory - and himself fixing an arbitrary penalty for avoidance! This is a clear assertion of effective territorial control. Lastly, he assumes that it is the European who is in a position to 'growl' and to punish either side of the dispute. There is no room to doubt the superior power of British justice.

9 Mulvaney and Green 1992: 140.

10 Mulvaney and Green 1992: 165.

11 Searcy 1907: 94-96. See also Macknight 1976: 110-111; Correspondence received in the office of the Minister controlling the Northern Territory, State Records of South Australia [hereafter SRSA] GRS 1 1884/445.

12 Searcy 1907: 63. 
There are other differences too. Barker, who was 44 at the time of these events, came from an educated background in England and had served in Sicily, Italy, Portugal, Spain, France, Canada and Ireland, before arriving in the Australian colonies. ${ }^{13}$ Searcy, who was only 30 at this stage of his career, had grown up in Adelaide and had not yet left South Australia other than on his voyage to Darwin. ${ }^{14}$ Yet what is most remarkable about Searcy is his capacity to transcend the grosser limits of his background; he has the imagination to realise that some others at least see the world differently. Many lacked such imagination.

They also lacked the benefit of Searcy's official position. The following letter, written on 30 March 1903 almost exactly a century after Flinders and Brown interviewed Pobassoo and about 20 years after Searcy was in Melville Bay, shows in its jumble of tangled syntax, prejudice and special pleading just how far the attitudes of some people on the ground - and with different interests - had changed. Copies of the letter were sent to various South Australian Government officials.

Sir,

I am trying to make a living down the Coast fishing and preserving 'Beche de Mer' commonly called 'Trepang' but find that on account of the Malay Proas being allowed to come over here yearly, it has such a debasing effect on the natives that a whiteman cannot get them to work.

The law prohibits us from giving the natives intoxicating liquors but the Malays are able to supply them with a great quantity, and so the blacks will not work unless they get a certain amount, and so we are only able to make a bare living.

Another thing is the Malays spread the venereal decease [sic] all along the Coast and shortly after the 'Proas' come it[']s no uncommon thing to see five or six men and women in a camp rotten. I saw three die on $\mathrm{C}[\mathrm{r}]$ oker Island last year, and young women too.

I am given to understand that the duty collected from the Malays only amount to about $£ 300$, and it takes all that to pay the expenses of collecting, and the said 'Proas' take away yearly between 4 \& 5 thousand pounds in fish, Turtle-Shell and Pearls.

Again, they are under the Dutch Flag, and are allowed to build houses and in fact live ashore for six months of the year in Australia, but if we should wish to go over say to the 'Auru' or Key Island, we are prohibited from fishing within (3 leagues') not three miles, and if only wanting wood and water, and go on shore for the same, we if [we are] caught stand a good show of losing our boat and plant. (Hardly fair - is it.) 
The general opinion of all of us that are trying to make a living down the Coast is that if the Malays were stopped from coming, that the Whites and Natives would benefit greatly and the industry would grow very shortly into a big sourse [sic] of revenue to the $\mathrm{N}$. T. but we cannot compete against the Malays whose Grog and Rice costs so very little in Maccassar [sic] ...

\section{Charles E. Gore ${ }^{15}$}

In the event, the government obtained more balanced and reliable information so that nothing in particular came of the charges in this and similar letters. ${ }^{16}$

A striking feature of the attitudes displayed in this letter is the emphasis on the territorial integrity of Australia, along with a recognition that the Dutch imperial power insists on a reciprocal claim. Both territories are seen as subject to the oversight and control of their respective governments. We should also note the depersonalised categories used: 'Malays', 'natives' or 'blacks', and even 'whitemen'. There is no sign that our letter-writer knows the name of any individual 'Malay' or 'native' as Searcy or Barker so clearly did. Nor is there any doubt about the priority of the various interests to be considered. Even if the 'natives' are to be protected from intoxication and disease, it is only so that they may supply more labour to 'white' enterprise. Lastly, and perhaps most importantly, we can see in the letter the assumption that all initiative lies with the writer and his kind, aided where necessary by the power of his government. If only the 'Malay' trepangers can be prohibited from coming by government regulation, then 'all of us that are trying to make a living down the Coast' will be free to develop the industry.

In the end, it was this final argument that led to the effective prohibition of the trepanging voyages from Makassar to the Northern Territory coast in 1906, but it was a complicated affair and a hollow victory for local enterprise. ${ }^{17}$

This review of the attitudes of contemporary observers of the trepanging industry in Australia reveals a gradual narrowing of sympathies over a period of about 100 years following Flinders' account. This is not just the result of the change in the intellectual climate from an earlier Enlightenment outlook to the Social Darwinism of the late nineteenth and early twentieth century, but even more importantly, a constriction of focus and a decline in knowledge. By contrast, in the century since then, a broadening of approaches to the study of the trepanging industry and ever wider sympathies among its students have gradually become apparent. These developments have affected the ways in which the impact of the industry, that is the interactions of the trepangers with local people and the longterm consequences of such interactions, has been understood.

15 Correspondence received in the office of the Minister controlling the Northern Territory, SRSA GRS 1, 1903/461. See also the very similar letter in SRSA GRS 1, 1903/438.

16 The wider context of these letters and their reception is described in Macknight 1976: 121.

17 For a detailed discussion of these events, see Macknight 1976: 122-126. 


\section{Widening views}

The first major ethnographic research in the area visited by the trepangers, that is along the coast from the Cobourg Peninsula to the bottom of the Gulf of Carpentaria, was conducted by Norman Tindale on Groote Eylandt in 1921 and 1922. This was, in a sense, accidental since Tindale's primary motive for the trip had been to collect entomological specimens for the South Australian Museum, though he had also made some preparations for ethnographic research, at least as it applied to working with Aboriginal people. Once in the field, however, he could not fail to record the abundant evidence of the former industry. A measure of his unfamiliarity with the origins of the trepangers can be seen in a research note from 1922; working with an informant, Rupert, a Nungubuyu man,

I asked him if the word 'sail' 'tumbula' of Ingura [Tindale's term for the main language spoken on Groote Eylandt] is Malay. Rupert says it is also the Macassar word, the Malay word being again different. If other words substantiate this one can fix the origin of the Malay traders who came here $\&$ are said yet to ocassionally [sic] trespass along the coast. ${ }^{18}$

In his published list of words 'probably all of foreign origin', he notes some possible Malay sources, but admits that the items in the list 'have not been compared with Macassar or Bugi vocabularies, in which the sources of some will probably be found' ${ }^{19}$

Today we should admire the typical precision of Tindale's observations rather than note his lack of access to sources on the finer points of linguistic and cultural divisions in the Indonesian archipelago. Throughout the 1920s and 1930s, the word 'Malay' continued to be the most common term to describe the trepangers and reference was made only to the Malay language for linguistic comparisons. This is well demonstrated in Jennison's excellent article from 1927 which draws on linguistic material from South Goulburn Island and from Elcho Island..$^{20}$ More famous is Warner's discussion of cultural influences based on his fieldwork at Milingimbi between 1927 and 1929. ${ }^{21}$ Warner uses the term 'Malay' consistently throughout his work. Thomson who worked extensively in eastern Arnhem Land in the late 1930s, but was publishing in the 1940s, is highly inconsistent in his usage of 'Macassar', 'Malay' and now 'Indonesian', though he thought that the trepangers brought a 'virile culture'. ${ }^{22}$

18 Quoted in Walter 1988: 66. This thesis provides an extended discussion of Tindale's work on Groote Eylandt and in many other places. Rupert's information is correct; the regular Makassar word is sombala', which derives ultimately from Sanskrit, while the usual Malay/Indonesian word is layar. In relation to the suggestion that trepangers were still trespassing, it is most unlikely that this was so. Tindale knew little of the history of the industry.

19 Tindale 1925-28: 132.

20 Jennison 1927.

21 This was first published as an article (Warner 1932), but the material has also appeared in the various editions of his great book, A Black Civilization. On Warner, see also Hamby 2008.

22 For example, see the use of these terms in Thomson 1949: 82-94, but similar casualness is also apparent in his other publications from the 1940s. 
It would be unfair to criticise researchers such as those just mentioned for not looking more closely at the trepangers themselves. After all, the central focus of these anthropologists was Aboriginal society. The work was also being done in Australia where, at that time, any investigation of the background in the Indonesian archipelago would have required access to scholarly - and linguistic - resources not readily available. One remarkable exception to this lack of interest is Tindale's reference to the Dutch publication of late sixteenth-century drawings to illustrate sails and vessel shapes similar to those known on Groote Eylandt. ${ }^{23}$

The situation is more complex with the work of Ronald and Catherine Berndt who conducted their research in various locations along the Arnhem Land coast between 1946 and 1951, with many later visits as well. They recorded an extraordinary body of ethnographic data, much of which they published with exemplary dispatch. Perhaps it was just this desire for speedy publication that meant that there is often some lack of analysis in their writing. Although there is reference to the trepangers and their influence on Aboriginal societies in many of the Berndts' multifarious books and articles, the most sustained account is to be found in their book, Arnhem Land: Its History and Its People, which was published in Melbourne in 1954. ${ }^{24}$ This is a treasure trove of information of all kinds: the published literature, archival sources from the South Australian records, and direct testimony from local informants. Whereas Tindale and Warner had been content to note that many men had travelled back to Makassar with the trepangers, the Berndts provide the detailed account of Charley Djaladjari with the names of many localities and words for specific items. ${ }^{25}$ For anyone familiar with Makassar, many details are instantly recognisable. For example, among the islands near Makassar listed by Djaladjari is 'Djamaluna island with its gardens and large water tanks. ${ }^{26}$ Samalona is a small coral cay, about seven kilometres off the coast directly in front of Makassar. Its main use these days is for recreation and there are no gardens, but tanks are still needed for water.

The Berndts are largely responsible for introducing four elements into the study of the trepangers which have, ultimately, proved unhelpful. The first is the word 'Macassan'. This term appears to have been first used in an article published in 1947, but deriving from their fieldwork in 1945 before they went to Arnhem Land. They write, 'Before white settlement, Chinese, Malayan, Javanese and Macassan traders in search of trepang, béche-de-mer, dugong oil, cowries,

23 See Tindale 1925-28: 132. The reference is to GP Rouffaer and JW Ijzerman (eds), De Eerste Schipvaart de Nederlanders naar Oost-Indië onder Cornelis de Houtman 1595-1597 (Linschoten Vereeniging VII), Martinus Nijhoff, 's-Gravenhage, 1915, pl. 27-28. The second plate does indeed show a vessel from South Sulawesi with a large rectangular sail among others seen by the Dutch along the north coast of Java. The then Public Library of South Australia, next door to the museum where Tindale worked, was one of only two subscribers in Australia to the Linschoten Vereeniging at the time; it registered its copy of the volume on 25 June 1915, about three months after publication.

24 In fact, my copy has the date of 11 December 1953 under the name of its first owner, so it may have been available a little before 1954 .

25 Berndt and Berndt 1954: 51-58.

26 Berndt and Berndt 1954: 58. 
etc., visited parts of the northern coast' ${ }^{27}$ This context suggests that they then knew little of the history of contact between north Australia and the archipelago and casually invented this new term. It has persisted. ${ }^{28}$ In part, this is because it helps to have some term by which to refer to those involved in the trepang industry and 'Macassan' serves easily as noun and adjective. Moreover, it does make the link with Makassar which was port of origin and return for the praus. The difficulty arises from confusion with the name of the cultural and linguistic group which provided most of the crew - and which also gave its name to the city which is officially known today as Makassar. To itself, this group is known as Mangkasara'; in Bugis, it is Mangkasa'; the most usual form in Malay or Indonesian is Makassar or Mengkasar; the modern Dutch form is Makassaars; while in English one finds Macassarese, Makassarese, Macassar and, my current preference, Makasar. It is important to state clearly that the term 'Macassan' (or 'Makassan') has no currency in an Indonesian context; it should not be used as an equivalent for 'Makasar'. ${ }^{29}$

The second difficulty introduced by the Berndts was to suggest, however tentatively, that the trepanging voyages began 'in the early sixteenth century' ${ }^{30}$ While many previous authors had offered guesses on when the industry began, this estimate looked more definite, although the 'tentative calculations' on which it was based were not given. Such a date before European contact with the continent has two consequences: it suggests that the observed effects of contact in Aboriginal societies arose over about 400 years and it serves the rhetorical purpose of distancing the industry from European contact. The matter of dating is further discussed below.

Thirdly, the Berndts described an overarching structure to the relationship between trepangers and Aborigines. They write:

With the coming of the Europeans, to which Flinders' visit served as a prelude, Macassan contact began a second phase that lasted until 1907. It was during this time that the traditional trading relationships between the Indonesians and the Aborigines became seriously strained. ${ }^{31}$

27 Berndt and Berndt 1947: 249.

28 The similarity in handwriting between the final ' $-\mathrm{n}$ ' and ' $-\mathrm{r}$ ' has also led to many examples of mis-transcription of nineteenth century manuscript sources. See, for example, my own error in Macknight 1969b: 66, note 3 and in Mulvaney and Green 1992: 135 and 163. I am confident that other examples, when checked against the original manuscript, would show the same mistake.

29 I myself have used the term 'Macassan' extensively, though I limit its meaning with some precision (Macknight 1976: 1-2). I now try to avoid it in all contexts. In the 1960s I took over the term from Mulvaney who, in turn, derived it from the Berndts. It is also widely used in the publications of the Records of the American-Australian Expedition to Arnhem Land in 1948, but note that McCarthy and Setzler offer a definition not very different from mine: 'By Macassan and Malayan we refer to the fishermen and traders from the islands northwest of Australia who visited the shores of Arnhem Land ... They came from Macassar in Celebes and from other Indonesian localities.' McCarthy and Setzler 1960: 287 note 67.

30 Berndt and Berndt 1954: 15.

31 Berndt and Berndt 1954: 73. 
Several previous ethnographers had generalised about the nature of these relationships. Tindale, for example, wrote that the attitude on Groote Eylandt 'towards the Malays was one of hate'. ${ }^{32}$ This view was confirmed by Worsley, though he noted that the passage of some three decades had softened and idealised the memory. ${ }^{33}$ I have argued that such generalisations are not sustainable and, indeed, some of the evidence presented above illustrates the variety of relationships. ${ }^{34}$ The element introduced by the Berndts, however, was to suggest two generalisations: generally good relations followed by generally bad relations. The lure of this narrative structure has proven hard to resist.

Lastly, there is a failure in much of the Berndts' writing from this period to distinguish clearly between material about which they have been told by informants and conclusions based on credible evidence; in other words, between myth and fact. A simple case is the manufacture of earthenware pottery in Australia. As the Berndts reported, the manufacture of pottery is described in songs they recorded, but this is not evidence to say, unequivocally, this happened in Australia. ${ }^{35}$ In fact, there is very strong evidence that most earthenware pottery found in Australia was manufactured in South Sulawesi, though some may come from elsewhere in the archipelago. It is highly improbable that any was made in Australia. ${ }^{36}$

A more complex example is the question of the 'Baijini'. While Mountford too, working at the same period as the Berndts, heard stories of the 'Baijini', ${ }^{37}$ the Berndts built an elaborate narrative which assigned contact with these people 'remembered particularly for the golden copper colour of their skin'38 to a period before 'Macassan' contact. The 'Baijini', it is claimed, settled on the coast; they built houses, grew food, wove cloth, as well as gathering trepang. ${ }^{39}$ As the Berndts themselves realised, much of this material is conflated with observations of the 'later' trepangers and a thorough analysis would require detailed knowledge of the realities of language and culture in Makassar, at least in the first instance. The Berndts offered a few hints only. While it has long been clear that the 'Baijini' stories as such do not reflect any historical reality in Australia, their presentation by the Berndts, and especially the claim of contact before the sixteenth century, has led to much confusion. ${ }^{40}$

In 1948 as part of the American-Australian Scientific Expedition to Arnhem Land, that is at more or less the same time as the Berndts were beginning their work in Arnhem Land, Fred McCarthy and Frank Setzler undertook the first significant archaeological investigation of sites associated with the trepangers.

32 Tindale 1925-28: 131.

33 Worsley 1954: 9-12.

34 Macknight 1972: 285-290.

35 Berndt and Berndt 1954: 43-44.

36 Macknight 1972: 309-310. Bulbeck and Rowley (2001) report further confirmation of this.

37 Mountford 1956: 333-338, 440-442.

38 Berndt and Berndt 1954: 34.

39 Berndt and Berndt 1954: 32-39.

40 The recent work of McIntosh on this material is discussed below. 
They excavated two graves on Winchelsea Island and recorded the usual signs of processing sites there and at two sites in Port Bradshaw. While they recognised the overall purpose of the sites, they did not analyse how the remains reflected the processes involved and, despite consulting the best available experts, they could get no useful dates for the pottery they collected. ${ }^{41}$ Although there is a general awareness of the former trepanging industry and the local influence of the trepangers throughout the publications from the 1948 expedition and McCarthy refers to an Indonesian publication relating to rock art in South Sulawesi, ${ }^{42}$ nowhere does McCarthy mention that he himself had been in Makassar ten years before.

This lack of awareness of the background to the industry in South Sulawesi was addressed in two magisterial articles in 1952. AA Cense, who had lately returned to the Netherlands after a long career in Indonesia and, as secretary to the Koninklijk Instituut voor Taal-, Land- en Volkenkunde, had access to its excellent library, reviewed the historical references to the industry and discussed the ethnographic publications from Australia, including the early articles of the Berndts. He also appended an account of the route taken by the praus from an old trepanger whom he had known in Makassar in the 1930s. ${ }^{43}$ In a note, Cense mentions that he had just seen an article by HJ Heeren, covering much the same material. ${ }^{44}$ Both articles analyse the evidence for cultural and other influences by the trepangers on Aboriginal societies on the basis of an excellent knowledge of the background of the trepangers themselves. It is unfortunate that their publication in Dutch has prevented many later researchers consulting them. Among Australian scholars of the period only Manning Clark seems to have engaged seriously with the Dutch sources and, in a slightly confused account of the industry, he refers to both these articles. ${ }^{45}$

\section{Modern understandings}

In 1961, John Mulvaney in his first overview of Australian prehistory discusses the trepangers under the title 'proto-historic influences' ${ }^{46}$ In 1963 and 1965 he visited various places around the coast of Arnhem Land to investigate the potential for archaeological research. A lecture on the industry he gave soon after returning from the second trip is full of insights, based on a remarkably

41 McCarthy and Setzler 1960: 220-223, 228-229, 287-294. It is important to note that in 1969, with further knowledge, Kamer Aga-Oglu amended her opinion on the date of one critical sherd (Macknight 1976: 162, n 22). Although not published until 1960, the text of McCarthy and Setzler's chapter on archaeology had been completed very much earlier, according to Dr Martin Thomas.

42 McCarthy 1960: 400.

43 Cense 1952. An English version of the account of the route appears in Macknight 1969b: 180-185.

44 Heeren 1952.

45 Clark 1962: 37-38.

46 Mulvaney 1961: 99-100. 
wide reading of the sources and the initial results of his fieldwork. ${ }^{47}$ When I began my PhD research under his supervision in 1966, he most generously made all his previous material available to me.

My doctoral thesis, which was submitted to the Australian National University in December 1969, described the trepanging industry conducted around the coast of Arnhem Land by men from Makassar; its chief point of originality, at least within the Australian literature, was to view the enterprise from the deck of a prau going south to Arnhem Land or Marege' as they called it, rather than looking from the beach at what was coming over the northern horizon. This was a move which, I remember, took some intellectual effort to achieve and it is not by chance that the book which eventually resulted from the thesis is entitled The Voyage to Marege'.$^{48}$ In large part, I set about a thorough reading of the sources already known from the work of those just mentioned, with a view to drawing these together into an overall account. Seasons of fieldwork in 1966 and 1967, however, added new aspects to my understanding.

It was a magic time to be doing fieldwork in coastal Arnhem Land: the various settlements could be reached by regular air services and small boats were available to reach nearby sites; the centralisation of control in the then Welfare Branch of the administration and the practical assistance of the Methodist Overseas Mission made many practical matters much easier to arrange than they have been more recently; to my surprise, delight and education, enough old men were still alive and willing to pass on significant information about the industry to an eager young listener; and the Australian National University provided adequate funding and many other resources.

Coming at the matter with a strongly archaeological approach, there were several questions that I managed to resolve. One was to understand the layout of a processing site and the actual processes involved..$^{49} \mathrm{By}$ visiting several dozen sites between Groote Eylandt and the Cobourg Peninsula - and excavating on many of them - it became clear that the trepangers had arranged their activities on a site in a standard pattern. Moreover, the artefacts collected on the surface and by excavation, including abundant earthenware, high-fired Chinese stoneware, Dutch gin bottles, copper fish-hooks, and Dutch coins, were remarkably similar from site to site and confirmed Makassar as the home port of the praus. ${ }^{50}$ Lastly, the sheer range of the sites emphasised the geographical spread over which the industry was conducted and the extensive opportunities for interacting with local people.

By the happiest of ironies, in 1969 Mulvaney followed up McCarthy's initiative from 1938 in investigating prehistoric sites in South Sulawesi with the hope

47 Mulvaney 1966.

48 Macknight 1969a, 1976.

49 My understanding of the processes involved has been much helped more recently by observing the modern methods in South Sulawesi and, more importantly, by information from friends at Tasmanian Seafoods Ltd, the firm which has resurrected a significant export industry in trepang.

50 These collections are now held in the Northern Territory Museum and Art Gallery in Darwin. 
of establishing links with Australia. With RP Soejono, he led a joint team of Australian and Indonesian archaeologists to revisit and re-excavate key sites. Even if nothing came of the hope of establishing prehistoric links between South Sulawesi and Australia, the 1969 expedition did open up collaboration with Indonesian archaeologists that has continued until the present. It also allowed me to visit Makassar for the first time and I met Mangngellai Daeng Maro who had come to Arnhem Land with his father in 1905-06 and 1906-07. I also went sailing on a prau very similar to those that had come to Australia and was able to check many details of my understanding of the general background.

This first visit inspired me to embark on a long-term research interest in the past of South Sulawesi. The subsequent growth in historical, archaeological and sociological understanding of the area - much more from the work of others than from my own efforts - has been spectacular. We know in very great detail about the place from which the trepangers came and about their intellectual and cultural world. We can now see the historical and cultural circumstances into which the industry fits both in general and in particular detail, such as burial practice or the nature of the earthenware pottery. ${ }^{51}$

One matter about which, for many years, I was not entirely happy was the question of the date at which the industry began, that is, when did trepangers from Makassar first start working along the coast of Arnhem Land and down into the Gulf of Carpentaria. In successive statements, I have gradually changed my position on the answer to this question. In the 1960s, I was concerned to argue against early dates, such as the Berndts' guess of the early sixteenth century quoted above. Given some evidence from the eighteenth century and unwilling to make too great a distinction between the industry along the Kimberley coast and in Arnhem Land, I opted for 'about the beginning of the eighteenth century'.$^{52}$ By 1976, I had discovered the Dutch report from Timor in 1754 referring to occasional voyages to the 'Southland' to collect trepang and wax and I had heard from Mangngellai Daeng Maro a legend about Makasar leaders escaping to the Gulf of Carpentaria after a defeat in 1667 and eventually bringing back the first cargo of trepang. I was then willing to suggest a date 'between about A.D. 1650 and 1750' with 'the most probable period within this century [being] the last quarter of the seventeenth century'. Moreover '[the industry] may well have begun in a small, irregular and secretive way. ${ }^{\prime 53}$ Ten years later and with Heather Sutherland's encouragement and guidance, I had begun to explore the Dutch archives and I suggested

subject to confirmation by more detailed archival work, that the whole trepang trade through Macassar was on a small scale and locally based in the mid 1720s. It had probably begun only a decade or so before [and]

51 Bulbeck and Rowley 2001.

52 Macknight 1969a: 391. I have never accepted at face value several early radiocarbon dates from my excavations. On this question, see Bulbeck and Rowley 2001: 59-60 and the sources they quote. Daryl Guse has recently taken some new samples from the same context at the Anuru Bay site as that which yielded one early date, but no results are yet available. 
as we know from other documentary sources, Macassan trepangers had certainly reached the north Australian coast by the middle of the eighteenth century. ${ }^{54}$

My current opinion is based on that 'more detailed archival work' as reported by Gerritt Knaap and Heather Sutherland. We now have a remarkably full account of the whole trade of Makassar through the eighteenth century which places the trade in trepang within its context. Not only was Makassar the point of trade for trepang from Australia, but it was - and remains - the centre of the trade for the whole archipelago. This new research confirms my suggestion that the trepang trade began a few years before 1720 and was initially very small. Up to the 1760s most trepang came from relatively close at hand and was exported first to Batavia, and thence to China. In the 1760s the average annual export was 3469 pikul (210 tonne). In the 1770s, by which time a large proportion of the trepang went directly to China in an annual junk, the export had grown to 4568 picul (276 tonne) and then in the 1780 s to 7068 pikul (428 tonne). ${ }^{55}$

If we combine the sudden jump in the quantity exported around 1780 with Pobassoo's statement to Flinders in 1803 that he was one of the first to come to Arnhem Land about 20 years before, backed up by later information obtained by Flinders in Kupang, it seems highly probable that it was Arnhem Land which provided the new quantities. I now believe that the industry in Arnhem Land began around $1780 .{ }^{56}$ The evidence indicating earlier activity in Australia, in particular the 1754 report from Timor, applies to the Kimberley coast, a point I did not realise clearly enough before.

Despite all the new evidence about the trade in trepang and other marine products during the eighteenth century, some puzzles remain. One is the lack of explicit mention in the eighteenth century records of praus bringing trepang from Marege', ${ }^{57}$ or for that matter, Kayu Jawa, the name used for the Kimberley coast. I previously suggested that Buton or Bonerate, as the nearest known ports on the route to Australia, might disguise the eventual destination, but the figures on the trade with these two places, though they do include significant quantities of trepang, make it clear that this explanation will not work. ${ }^{58}$ Yet the name, Marege', was certainly known in the late eighteenth century as it is applied to a type of trepang in a 1788 list. $^{59}$ A possible explanation may lie in the wide gap between the import figure and export figure for trepang and other marine products as recorded. Thus of the 428 tonne of trepang annually exported, on average, in the $1780 \mathrm{~s}$, only 167 tonne is identified as import. ${ }^{60}$ In this systematic under-reporting of imports - which is seen throughout the century in the figures for other maritime products as well - there is plenty of room to accommodate

54 Macknight 1986: 70.

55 Knaap and Sutherland 2004: 99-102.

56 This point is argued more fully in Macknight 2008a: 136-137.

57 This name is used in the comparable records from the 1840s. See Macknight 2008a: 138.

58 Macknight 1986: 70; Knaap and Sutherland 2004: 142-143.

59 Knaap and Sutherland 2004: 232.

60 Knaap and Sutherland 2004: 99. 
very large quantities of cargo from Arnhem Land, though it is not clear why such items were not noticed. ${ }^{61}$ Since a large proportion of the export went on a single junk to China, it seems likely that the export quantity is reasonably accurate. If so, the considerable quantity of trepang must have been imported from somewhere.

Another puzzle is what to make of the legend that some of the Gowa fleet from Makassar, defeated by the Dutch at Buton in 1667, made their way to the north Australian coast. ${ }^{62}$ While there could be an element of truth here, it is strange that no one has yet noticed a reference to the matter in the abundant and much studied written sources for the period. It is also difficult to see any link with the beginning of the trepang industry in Australia, given what we otherwise know about the history of the trade.

In 1972 I published a review of all the claims which had then been made of ways in which the trepangers had influenced Aboriginal people in the Northern Territory ${ }^{63}$ It is now worth asking how the new precision in our understanding of the nature and date of the industry affects the question of influence. The extent of that influence has continued to receive considerable scholarly attention.

Some of this work has filled out, but not significantly changed, the points I made in 1972. The best example is in the matter of language where far greater expertise and experience in Aboriginal linguistics has been matched by access to modern sources from across the archipelago. ${ }^{64}$ By a remarkable stroke of good fortune, however, we have in the works of BF Matthes, the nineteenth-century Dutch Bible translator, and especially in his Makasar dictionary, a detailed, contemporary account of the main language used by the trepangers, along with many other details of their life. ${ }^{65}$

In two areas, further work has significantly transformed and extended my earlier understanding. Both involve the long-term ramifications, within Aboriginal societies, of changes and material deriving from contact with the trepangers. While the initial outcome of the contact has long been apparent, it is now clear that there have also been more complex consequences.

61 Knaap and Sutherland (2004: 98) offer some suggestions to explain the discrepancy relating to trepang specifically and especially that not coming from regular centres of trade. As their work continually makes clear, the figures merely reflect the records and are averages; particular circumstances and arrangements may often have made the reality somewhat different from year to year. In addition, policy and implementation differed across the decades. Yet whatever the problems of detail, there can be no question of the cogency of their main conclusions drawn from sources across the century, in this case the steady growth of the trepang export - and import from the 1720s, with a marked rise in the 1780s.

62 Macknight 1976: 96.

63 Macknight 1972.

64 Walker and Zorc 1981; Evans 1992, 1997. Some of the suggestions by Urry and Walsh (1981) seem excessively speculative.

65 Matthes 1859. Much later work on the language confirms the value of this dictionary and associated materials. 
Over many years, Ian McIntosh has developed an analysis of the 'Baijini' stories of north-eastern Arnhem Land, mentioned above. Whereas the Berndts presented the stories as evidence for actual historical events in a 'pre-Macassan' phase of contact, McIntosh accepts the difficulties with this interpretation and sees the specific material as deriving from Aboriginal experience with the trepangers, especially on visits to Makassar. ${ }^{66}$ He then moves on, however, to consider what Aboriginal thinkers have done with this material and describes the sophisticated intellectual structure they have developed to account for the relations between outsiders and themselves. This takes the question of influence far beyond the mere transference of particular cultural items from one group to another. McIntosh traces the ways in which the memory of historical events - in this case the well documented visits to Makassar and elsewhere by Aboriginal men in the nineteenth century - can produce outcomes which ramify through the thinking of succeeding generations. The analytical task for research on these stories is to tie particular elements to the observed nineteenth-century reality and trace out the transformations. ${ }^{67}$

A good example of the richness of this approach can be seen in McIntosh's treatment of the Aboriginal - and more specifically his informant and friend Burrumarra's - understanding of Islamic matters. He shows how the wurramu ceremony, as described by Warner and the Berndts and observed by himself, has both an 'outside' meaning with various relatively straightforward historical references and an 'inside' meaning referring to underlying power relationships and their transformations. Various songs are based on Arabic prayers, though their meaning as understood by any pious Muslim is now not recognised. What makes this material of particular interest is the excellent chronological control over the three stages of the process. It is highly unlikely that anyone in Arnhem Land has heard the Muslim prayers since the last trepangers from Makassar went home in 1907 - at least until very recent times and in a completely different context. Next, we have Warner's record of the songs from the early 1920s, confirmed by the Berndts' material from around 1950. Though the Berndts knew Burrumarra as a young man, McIntosh is reporting his mature reflections on the material from the 1990s. There is no reason to suppose that this is the end of the process of re-working and re-interpretation. ${ }^{68}$

In a similar way, but with very different materials, Scott Mitchell has traced out the economic ramifications of contact with the trepangers, especially for the people of the Cobourg Peninsula. While Rose had long ago hypothesised that the availability of dug-out canoes had transformed the economic possibilities and allowed a larger population on Groote Eylandt, ${ }^{69}$ Mitchell shows, with some very elegant archaeology, how more recent middens in his study area

66 This is essentially my position over many years. See Macknight 1972: 313; $2008 \mathrm{a}: 144$.

67 See McIntosh (2008) for his most recent account, with references to earlier papers.

68 See McIntosh 1996. Both Cense (1952) and Heeren (1952) have dealt in detail with the derivation of the songs and expressions in question and on the basis of a good understanding of the Islamic originals. McIntosh seems not to have consulted them.

69 Rose 1961. 
reflect an economy more focussed on marine resources only accessible with reliable watercraft. ${ }^{70}$ Again, we can see the consequences of influence, as well as the simple observation that dug-out canoes and their making were derived from contact with the trepangers. Since the widespread use of the canoes by local people must derive from considerable contact - that is, from a period when the industry was reasonably well established - this must be after about 1780. By 1839 at the latest, however, Aborigines on the Cobourg Peninsula were manufacturing the canoes. ${ }^{71}$ The speed of the Aboriginal response is both impressive and instructive. While Thomson had proposed that access to certain material goods had given a special impetus to the ceremonial exchange cycle, ${ }^{72}$ Mitchell's material suggests the transformative effect of new technology, rather than merely the intensification of existing features of the economy.

In one area, I quite failed in 1972 to see the implications of the data; that is the introduction of smallpox. Although I listed the evidence suggesting that this disease was derived from contact with the trepangers, ${ }^{73}$ I did not then link this with the widespread smallpox epidemics which afflicted most of the continent. The whole topic is now definitively covered by the work of Judy Campbell. ${ }^{74}$ There can be no serious doubt that the several epidemics in the nineteenth century began in northern Australia and spread southwards and, though much work remains to be done in elucidating the history of the disease in the archipelago, there is no difficulty in sourcing the infection back to Makassar. Indeed Robert Brown, with Flinders, noted traces of smallpox among the men he met in $1803 .^{75}$ Much work is also needed to trace the limits of the epidemics and the scale of mortality in different parts of the continent.

There has been much debate in recent years about the origin of the smallpox observed in Sydney in April 1789 and no little ingenuity displayed to suggest that it could have been derived from the British settlement. ${ }^{76}$ Such a conclusion seems to me both far-fetched and unnecessary. The overwhelming probability must be that it was introduced, like the later epidemics, by trepangers on the north coast and spread across the continent to arrive in Sydney quite independently of the new settlement there. If, about 1780 , the trepang industry brought large numbers of men from the archipelago to Arnhem Land for the first time, the date of the epidemic's arrival in Sydney, with its terrible effects on a relatively dense, but entirely virgin population, makes a great deal of sense.

70 Mitchell 1994, 1995, 1996.

71 Cameron 1999: 55.

72 Thomson 1949.

73 Macknight 1972: 292-293.

74 Campbell 2002. See also Macknight 1986.

75 Brown's journal 18 February 1803 British Museum (Natural History). In view of the interest in this question, it is worth transcribing all that Brown says on the matter: 'In the small pox they use the cold affusion. The water is procur' $\mathrm{d}$ as cool as possible \& during the eruptive fever is pour' $\mathrm{d}$ on the patient 3 times a day, viz early in the morning, at noon \& at $6 \mathrm{PM}$. If this practise is not regularly follow'd with a strict attention to the hours the patient commonly dies. Among the people we saw very few were pitted by the small pox \& those very slightly.' See also Brown 2001: 373, but I have worked from the original.

76 Butlin 1983; Warren 2007; Mear 2008. 
I recently had the pleasure of returning to western Arnhem Land where Daryl Wesley is re-investigating some trepang processing sites to understand more details of the conditions of contact between the trepangers and local people. He and his team are also systematically studying the rock art of the Wellington Ranges, some 10 to 20 kilometres inland, which shows much evidence of this contact. Here again, it may be the abundance of such art, as well as the motifs themselves, which reveals changes in Aboriginal ways of thinking.

\section{Conclusion}

There sometimes seems to be no end to the possibilities of tracing the eddying whirlpools of the trepangers' influence in indigenous societies. In 1972, I used another metaphor when I summed up their impact:

Macassan influence contributed merely an exotic colour to the cultural fabric of certain Aboriginal societies. While this colour might well have become more marked had the contact been more prolonged, the underlying pattern was still very clear, even in areas of strongest influence.

In essence, this remains a valid assessment. Within a 'traditional' context, the people of the Cobourg Peninsula, or Groote Eylandt, or north-eastern Arnhem Land, or anywhere else across the continent whose lives were changed either directly or indirectly as a result of the trepangers visiting the north coast retained the essential character of their languages, economy, social organisation, religious belief and symbolic system.

The metaphor, however, is too simple and too static. It misses the sense of agency and the complexity of process that we can now discern. It fails to notice the importance of Aboriginal response immediately, or over time, and it has no space for the role of the individual. Moreover, if we consider the history of northern Australia into the 'non-traditional' present, many more agents and externally-driven processes need to be taken into account. Within this history, the memory of the trepang industry from Makassar can be, and has been, put to a wide variety of uses for a diverse set of interests. ${ }^{77}$

Flinders' account of his meeting with the trepanging fleet made the industry's existence known to a very wide audience and this now passes for general knowledge, especially in northern Australia. In particular, for contemporary historians of Aboriginal experience, the story of the trepang industry and the outcome of interactions between the trepangers and Aborigines is a well-known theme. Today, we can also, with some assurance, place these matters within an emerging regional history. Modern Australians look north-west towards to Makassar with considerable understanding of the history and present circumstances of that area. It is not true to say, however, that the wheel has come

77 See Macknight 2008a. 
full circle since Flinders and Brown asked Pobassoo about the 'ippo' poison; we know far more than they or any of their contemporaries did. What we can do, two centuries later, is to share their expansive and inclusive view of the region's affairs.

\section{Acknowledgements}

I wish to thank the two anonymous referees, Greg Lockhart, Elizabeth Macknight and, especially, David Bulbeck for comments on earlier versions of this paper.

\section{References}

\section{Primary sources}

Arsip Nasional Republik Indonesia, Jakarta, Arsip Makasar, 354.4.

Brown journal, 18 February 1803, British Museum (Natural History), London.

Correspondence received in the office of the Minister controlling the Northern Territory, State Records of South Australia (SRSA) GRS 1 1884/445, 1903/438, $1903 / 461$.

\section{Secondary sources}

Berndt, RM and CH Berndt 1947, 'Card games among Aborigines of the Northern Territory”, Oceania 17: 248-269.

- 1954, Arnhem Land: Its History and Its People, Cheshire, Melbourne.

Brown, Robert 2001, Nature's Investigator - the Diary of Robert Brown in Australia 1801-1805, TG Vallance, DT Moore and EW Groves (eds), Australian Biological Resources Study, Canberra.

Bulbeck, David and Barbara Rowley 2001, 'Macassans and their pots in northern Australia', in Altered States: material culture transformations in the Arafura region, Clayton Fredericksen and Ian Walters (eds), NTU Press, Darwin: 55-74.

Butlin, NG 1983, Our Original Aggression: Aboriginal Population of Southeastern Australia 1788-1850, Allen \& Unwin, Sydney.

Cameron, JMR 1999, Letters from Port Essington, Historical Society of the Northern Territory, Darwin.

Campbell, J 2002, Invisible Invaders: Smallpox and other Diseases in Aboriginal Australia 1780-1880, Melbourne University Press, Carlton South. 
Carroll, DJ 2005, 'William Marsden and his Malayo-Polynesian Legacy', PhD thesis, Australian National University, Canberra.

Cense, AA 1952, 'Makassaars-Boeginese prauwvaart op Noord-Australië', Bijdragen tot de Taal-, Land-en Volkenkunde 108: 248-264.

Clark, CMH 1962, A History of Australia I: From the Earliest Times to the Age of Macquarie, Melbourne University Press, Parkville.

Earl, GW 1846, Enterprise in Tropical Australia, Madden \& Malcolm, London. [reprinted with introduction by RHW Reece, NTU Press, Darwin, 2002.]

Evans, N 1992, 'Macassan loanwords in Top End languages', Australian Journal of Linguistics 12: 45-91.

- 1997, 'Macassan loans and linguistic stratification in western Arnhem Land', in Archaeology and Linguistics: Aboriginal Australia in global perspective, $\mathrm{P}$ McConvell and N Evans (eds), Oxford University Press, Melbourne: 237-260.

Flinders, M 1814, A Voyage to Terra Australis, 2 vols and atlas, Nicol, London.

Gammage, B 1981, 'Early boundaries of New South Wales', Historical Studies 19: 524-531.

Hamby, Louise 2008, 'The reluctant collector: Lloyd Warner', in The Makers and Making of Indigenous Australian Museum Collections, Nicolas Peterson, Lindy Allen and Louise Hamby (eds), Melbourne University Press, Carlton: 355386.

Heeren, HJ 1952, 'Indonesische cultuurinvloeden in Australië', Indonesië 6: 149_ 159.

Jennison, JC 1927, 'Notes on the language of the Elcho Island Aborigines', Transactions of the Royal Society of South Australia 51: 177-192.

Knaap, G and H Sutherland 2004, Monsoon Traders: Ships, Skippers and Commodities in Eighteenth-century Makassar, KITLV Press, Leiden.

McCarthy, FD 1960, 'The cave paintings of Groote Eylandt and Chasm Island', in Records of the American-Australian Scientific Expedition to Arnhem Land, 2 (Anthropology and Nutrition), CP Mountford (ed), Melbourne University Press, Parkville: 297-414.

- and FM Setzler 1960, 'The archaeology of Arnhem Land', in Records of the American-Australian Scientific Expedition to Arnhem Land, 2 (Anthropology and Nutrition), CP Mountford (ed), Melbourne University Press, Parkville: 215-295. 
McIntosh, Ian S 1996, 'Islam and Australia's Aborigines? A perspective from North-East Arnhem Land', Journal of Religious History 20: 53-77.

- 2008, 'Pre-Macassans at Dholtji? Exploring one of north-east Arnhem Land's great conundrums', in Strangers on the Shore: Early Coastal Contacts in Australia, Peter Veth, Peter Sutton and Margo Neale (eds), National Museum of Australia, Canberra: 165-180.

Macknight, CC 1969a, 'The Macassans: a study of the early trepang industry along the Northern Territory coast', PhD thesis, Australian National University, Canberra.

- 1969b, The Farthest Coast: a selection of writings relating the history of the northern coast of Australia, Melbourne University Press, Carlton.

- 1972, 'Macassans and Aborigines', Oceania 42: 283-321.

- 1976, The Voyage to Marege': Macassan Trepangers in Northern Australia, Melbourne University Press, Carlton.

- 1986, 'Macassans and the Aboriginal past', Archaeology in Oceania 21: 69-75.

- 1988, 'Alfred Searcy', in Australian Dictionary of Biography vol 11 (1891-1939), G Serle (ed), Melbourne University Press, Carlton: 559-560.

- 2008a, 'Harvesting the memory: open beaches in Makassar and Arnhem Land', in Strangers on the Shore: Early Coastal Contacts in Australia, Peter Veth, Peter Sutton and Margo Neale (eds), National Museum of Australia, Canberra: 133-147.

- 2008b, 'A Useless discovery? Australia and its people in the eyes of others from Tasman to Cook', The Globe: Journal of the Australian Map Circle 61: 1-10.

Matthes, BF 1859, Makassaarsch-Hollandsch Woordenboek ... en verklaring van een tot opheldering bijgevoegden Ethnographischen Atlas, Frederick Muller, Amsterdam.

Mear, Craig 2008, 'The origin of the smallpox outbreak in Sydney in 1789', Journal of the Royal Australian Historical Society 94(1): 1-22.

Mitchell, S 1994, 'Culture contact and indigenous economies on the Cobourg Peninsula, northwestern Arnhem Land', PhD thesis, Northern Territory University, Darwin.

- 1995, 'Foreign contact and indigenous exchange networks on the Cobourg Peninsula, northwestern Arnhem Land', Australian Aboriginal Studies 1995/2: 44-48. 
- 1996, 'Dugongs and dugouts, sharptacks and shellbacks: Macassan contact and Aboriginal marine hunting of the Cobourg Peninsula, north western Arnhem Land', Bulletin of the Indo-Pacific Prehistory Association 15: 181-191.

Mountford, CP 1956, Records of the American-Australian Scientific Expedition to Arnhem Land, 1 (Art, Myth and Symbolism), Melbourne University Press, Carlton.

Mulvaney, DJ 1961, 'The stone age of Australia', Proceedings of the Prehistoric Society 27: 56-107.

- 1966, 'Beche-de-mer, Aborigines and Australian history', Proceedings of the Royal Society of Victoria 79(2): 449-457.

- and N Green 1992, Commandant of Solitude: the Journals of Captain Collet Barker 1828-1831, Melbourne University Press, Carlton.

Rose, F 1961, 'The Indonesians and the genesis of the Groote Eylandt society, northern Australia', Beiträge zur Völkerforschung, Veröffentlichungen des Museums für Volkerkunde zu Leipzig 11.

Searcy, A 1907, In Australian Tropics, Kegan Paul, Trench, Trubner, London.

Spillett, Peter G 1972, Forsaken Settlement: An Illustrated History of the Settlement of Victoria, Port Essington North Australia 1838-1849, Lansdowne, Melbourne.

Thomson, DF 1949, Economic Structure and the Ceremonial Exchange Cycle in Arnhem Land, Macmillan, Melbourne.

Tindale, NB 1925-28, 'Natives of Grooote Eylandt and of the west coast of the Gulf of Carpentaria, Parts I and II', Records of the South Australian Museum 3: 61-134.

Urry, J and M Walsh 1981, 'The lost “Macassar language" of northern Australia', Aboriginal History 5: 91-108.

Walker, A and RD Zorc 1981, 'Austronesian loanwords in Yolngu-Matha of northeast Arnhem Land', Aboriginal History 5: 109-134.

Walter, Karen R 1988, 'The proper breadth of interest Norman B. Tindale: the development of a fieldworker in Aboriginal Australia 1900-1936', MA thesis, Australian National University, Canberra.

Warner, WL 1932, 'Malay influence on Aboriginal cultures of north-eastern Arnhem Land', Oceania 2: 476-495.

Warren, Christopher 2007, 'Could First Fleet smallpox infect Aborigines? - a note', Aboriginal History 31: 152-164. 
Worsley, PM 1954, 'The changing social structure of the Wanindiljaugwa', PhD thesis, Australian National University, Canberra.

Yule, H and AC Burnell 1903, Hobson-Jobson: a Glossary of Anglo-Indian Colloquial Words and Phrases, Routledge \& Kegan Paul, London. 